\title{
Ozone and Its Role in Periodontal Therapy-A Review
}

\author{
Dr.Vinutha R.S , BDS ${ }^{1}$, Dr. Reema Lakshmanan, $\mathrm{MDS}^{2}$ \\ ${ }^{\text {I}}$ (Saveetha Dental College/ Saveetha University, India) \\ ${ }^{2}$ (Department of Periodontics, Saveetha Dental College / Saveetha University, India )
}

\begin{abstract}
Ozone is a colourless gas derived from oxygen and is present in the atmosphere. It is one of the most important gas in the stratosphere formed as a result of combination of three oxygen atoms on exposure to ultra violet rays. It is a powerful oxidiser and has been routinely used in human medicine to kill bacteria, fungi and to inactivate viruses. The nascent oxygen released by the spontaneous breakdown of ozone combines with the water molecules to form hydroxyl group $(\mathrm{OH})$ which is a more powerful oxidiser. It has been widely used in dentistry because of its antimicrobail property.Other properties are immune stimulating, analgesics, anti hypoxic, detoxicating, bio energetic and bio synthetic. Its role as an adjunct in periodontal therapy has been highlighted. However, the ozone toxicity and the susceptibility of individuals validate the need for studies focusing on the genetic aspect of the expression of the antioxidant genes in different ethnic groups.
\end{abstract}

Keywords: Ozone, Periodontitis, Nascent oxygen, Antimicrobial, Antioxidant gene.

\section{Introduction}

Ozone is a colourless gas form of oxygen and is present in atmosphere. It is one of the most important gas in the stratosphere formed as a result of combination of three oxygen atoms on exposure to ultra violet rays [1].It is also formed by the action lightening discharges and also has the capacity to absorb harmful UV rays[2].

In 1785, Van Marum noticed that the air next to his electrostatic machine acquired a characterstic odour when electric sparks were passed. In 1840, Schonbein named the gas "ozone". It is derived from the greek word "Ozein" meaning odorant. [3]. It is a pale blue gas that condenses to a deep blue liquid at very low temperatures [2]. It is unstable and quickly gives up the nascent oxygen to form oxygen. Hence, ozone is a powerful oxidiser and has been routinely used in human medicine to kill bacteria, fungi and to inactivate viruses[4]. The nascent oxygen released by the spontaneous breakdown of ozone combines with the water molecules to form hydroxyl group $(\mathrm{OH})$ which is more powerful oxidiser[5,6].

\section{Biological Actions}

There are several actions of Ozone in human body such as immune stimulating and analgesics, anti hypoxic and de toxicating, anti microbial, bio energetic and bio synthetic(activation of metabolism of carbohydrates, proteins, lipids etc)[7].

2.1 Antimicrobial Effect: The antimicrobial effect of ozone is as a result of disruption of cytoplasmic membrane of the bacteria due to the ozonolysis of dual bonds and oxidation of intracellular proteins. This action is however uneffective against human cell types. The reason attributed is antioxidant ability of the mammalian cells[8].

Thanomsub et al in 2002 demonstrated the effect of ozone treatment on cell growth and structural changes in bacteria such as Escherichiia coli, Salmonella sp., Staphylococcus aureus and Bacillus subtilis. Ozone at 0.167 $\mathrm{mg} / \mathrm{min} / \mathrm{l}$ can be used to sterile water which is contaminated upto $105 \mathrm{cfu} / \mathrm{ml}$ bacteria within $30 \mathrm{mins}$. Destruction of bacterial cell membrane, intercellular leakage and cell lysis was observed[9].

Unlike bacteria viruses multiply with in the host cell. They are small independent particles built of crystals and macromolecules. They consists of external protein shell called capsule with an interior nucleic acid core . Ozone destroys the viruses by diffusing through the protein coat into the nucleic acid core. This results in viral RNA damage and prevents the formation of viral proteins the virus infected cells are also intolerant to peroxides and hence gets inactivated in the presence of increased concentration of ozone[10,11].

2.2 Immuno stimulating Effect: Ozone influences cellular humoral immune system. It helps in the synthesis of immunoglobulin, activates macrophages and increases the sensitivity of microorganism to phagocytosis. In response of ozone the immune cells sets off a cascade of events through cytokinese which upregulates immune front and aids in resisting the disease. Hence, ozone holds promise for immune activation in immune compromised patients[12].ozone in high concentration is known to cause immune depressive effect whereas in low concentration it is immune stimulating in nature[13].

2.3Anti hypoxic effect: Ozone brings about the rise of partial pressure of oxygen in tissues and improves transportation of oxygen in blood. This results in the activation of aerobic processes. Low doses of ozone and repeated exposure activates anti oxidants like super oxide dismutases and catalases. It also prevents erythrocytes from aggregating and increases contact surface of oxygen transportation. This ability is used for oxygenation to revitalise the tissues in circulatory disorders[14]. 
2.4 Biosynthetic Effect: activates protein synthesis by increasing ribosomes and mitochondrial activity of cells hence ozone application is known to increase functional activity and to regenerate the tissues.

2.5 Angiogenesis: Ozone is known to activate angiogenesis[15]. This process is brought about by the secretion of vasodialators like nitric oxide (NO).Nitric oxide causes vasodialation of arterioles and releases growth factors like Vascular Endothelial Growth Factor (VEGF) which helps in angiogenesis[14].

Forms of ozone application: Gaseous ozone, Ozonated water.

\section{Ozone in Endodontics:}

Ozone has also remineralisation potential. It helps in clearing the smear layer and opens the dentinal tubules and enables diffuse of calcium and phosphorus ions to deeper layers of carious cavities. However long cavitated lesions are more likely to reverse than cavitated lesions.[16-20]. Holmes et al in 2003 demonstrated that application of ozone is capable of clinically reversing the lethary root carious lesions[21].ozone has also been documented to reduce the root hyper sensitivtity for longer period of time. This is also by the above mentioned mechanism by removing the smear layer in widening the dentinal tubules. This enables calcium and fluoride to flow effectively in to the tubules, plugging them and prevents sensitivity[22].

\section{Ozone application in Periodontics:}

Periodontitis is a multifactorial diseases characterised by the interaction of microbes and the host response. In the subgingival environment apart from the bacteria viruses and fungi have also been found which is associated with diseases initiation. Involvement of herpes virus in the etiology of periodontal diseases was suggested by Cappuyns I et al in 2005[23]. Similarly Jarvensivu A et al in 2004 recovered Candida albicans in the periodontal tissues of Juvenile periodontal patients[24]. Thus, removal of dental plaque forms an important part of controlling and treating periodontitis which brings about both quantitative and qualitative changes in subgingival microflora[25].

Ecological plaque hypothesis suggests that disease is prevented not by inhibiting the putative pathogens alone but also by interfering with the factors responsible for the transition of plaque microflora from the commensal to a pathogenic relationship with the host[26]. The critical event in ecological plaque hypothesis is breakdown of microbial hemostasis and shifting the ecological balance of plaque back towards one that is compatible with dental health[27]. Thus preventing strategies include altering subgingival environment which includes application of oxygenating agents[28]. An alternative approach by the suppression of subgingival bacteria is to inhibit their growth by changing subgingival environment (anaerobic) to aerobic[29].

\subsection{Anti microbial Properties:}

Ebensberger et al studied the effect of irrigation with ozonated water in periodontal ligament cells from freshly extracted erupting third molars. irrigation with isotonic sterile saline served as control group. Samples were studied immunohistochemically . it is found that teeth irrigated with ozone had a higher number of proliferating cell nuclear antigen(PCNA) than the control group. However, the difference was not statistically significant. Therefore they concluded that non isotonic ozone water not only helps in mechanically cleaning it doesnot have effect on periondontal cells[30].

Nagayoshi et al in a study found that ozonated water was useful in controlling oral infectious microorganisms in dental plaque. Dental plaque samples were collected and treated with $4 \mathrm{ml}$ of ozonated water for $10 \mathrm{secs}$. He found that it was effective for killing gram-positive and gram-negative oral microorganisms and oral candida albicans[31].

Ramzy et al in a study of 22 patients suffering from aggressive periodontitis(age 13 to 25years) irrigated in periodontal pockets with $150 \mathrm{ml}$ of ozonated water over 5 to 10 minutes once weekly for a four week study using blunt tipped sterile plastic syringe. He found that significant amount of reduction in pocket depth, plaque index, bacterial count in sites treated with ozonized water together with scaling and root planning[32].

Kshitish and Laxman conducted a randomized, double-blind, crossover spilt-mouth study on 16 patients suffering from generalised chronic periodontitis. The study was 18 days period of divided into two-time intervals from baseline to $7^{\text {th }}$ day with a washout period of 4daysfollowed by a second time period of 7 days. Subgingival irrigation of each of the mouth was done with chlorhexidine and ozone at different time intervals. They observed higher percentage of reduction in plaque index(12\%), gingival index(29\%), bleeding index(26\%) using ozone irrigation as compared to chlorhexidine. The reduction of $\mathrm{Aa}(25 \%)$ using ozone was more effective than compared with chlorhexidine. The antifungal effect of ozone from baseline(37\%) to $7^{\text {th }}$ day $(12.5 \%)$ was found during study period, unlike CHX which do not have any antifungal effect. They concluded that the substantivity of chlorhexidine, the single irrigation of ozone is quite effective to kill microorganisms [33].

Dodwad et al in 2011 compared the effect of oral irrigation with ozonated water, $0.2 \%$ chlorhexidine and $10 \%$ Povidine iodine in patients with chronic periodontitis. The study concluded that application of ozone served as a 
antimicrobial agent for treating periodontal disease non-surgically for both homecare and professional practice and also helps during supportive periodontal therapy[34].

\subsection{Wound Healing:}

Filippi found that application of ozonized water on daily basis can accelerate the wound healing process in first two post operative days in oral mucosa[35].

\subsection{Periimplantitis:}

Study by Karapetian et al treatment with ozonated water was found that the most effective bacterial reduction than compared to conventional and surgical procedures[36].

\section{Routes of Administration}

5.1 Gaseous ozone: ozone can be used in gaseous form via a sealing suction system to avoid inhalation and its adverse effects.

5.2 Ozonated water: is very effective against bacteria, fungi, viruses and its prefer to control oral infections because of the toxic effects of ozone gas. Huth et al in 2006 found that acquoes form of ozone showed less cytotoxicity than gaseous ozone or established anti microbial( like sodium hypochlorite, hydrogen peroxide, chlorhexidine) therefore aqueous ozone fulfils optimal biocompatibility for oral application[37].

Hems and Gulabivala in 2005 evaluated that the effect of ozone as an anti-bacterial agent using Enterococcus faecalis as a test species. Ozone was used both gasiform and aqueous form. Finally concluded that ozone in aqueous form was effective against Enteroccocus faecalis than gasiform ozone[38].

5.3 Ozonised oil: sunflower ozonised oil is widely accessibly and is competitive microbial agent and is effective against a variety of fungal and bacterial infections[39].

\section{Ozone toxicity:}

Ozone inhalation can be toxic to pulmonary system. Side effects are epiphora, upper respiratory irritation, cough, headache, rhinitis, nausea, vomiting, shortness of breath, poor circulation, blood vessel swelling, heart problems and at times stroke[40]. Ozone is a principle mediator of oxidative stress. Oxidation products can directly injure tissues or serve as exogenous ligands via binding cell surface. Thereby triggering intracellular inflammatory and or apoptotic signalling. Ozone derived oxidation stress leads to production of reactive oxygen species(ROS) which modifies innate immune signalling, upregulation of anti oxidant genes and enhance release of damage associated molecular pattern. Ozone exposure can directly lead to development of oxidized intermediates which is formed in the epithelial lining fluid or on modified cell surface proteins and lipids[41]. Ozone can result in lipid peroxidation or ozonation which damages the structure of cell membrane. Lipid ozonation products(LOP) produced during exposure of ozone which also appear to cause epithelial cell death and induce pro inflammatory cytokines production[42,43]. Tight regulation of oxidant stress is required to resolve tissue injury and maintain homeostasis. In addition, exposure to ozone can result in enhanced expression of many antioxidant gene. $\mathrm{NAD}(\mathrm{P}) \mathrm{h}$ quinone oxidoreductase(NQO1), heme oxygenase -1(HMOX1), and glutathione-s-transferase isoforms M1 and P1(GSTM1 and GSTP1) are critical detoxification enzymes in antioxidant defense. In human population studies, polymorphism of NQO1,HMOX1,GSTP1 and GSTM1 are associated with host susceptibility to ozone exposure although these appear to be complex $[44,45,46]$.

\section{Conclusion}

Scientific research suggests that ozone therapy has great potential in treatment of various conditions in dental problems and to inactivate viruses, fungi and bacteria. Further research is needed to standardise indication and treatment procedures.

\section{References}

[1] Grootveld, Baysan A, Siddiqui N,Sim J,Silwood C,Lynch E,editor,Ozone the revolution in dentistry,London, Quintessence Publishing Co,2004,23-30.

[2] Gupta G, Mansi B, Ozone therapy in periodontics,Journal of medicine and life,5,2012,59-67.

[3] Sameer M, Monica M,Ozone treating dental infections, Ind J Stomatol,2,2011,256-9.

[4] Garg R.Tandon S. Ozone A new face of dentistry, The internet journal of dental science,7,2009,2.

[5] Finlayson-Pitts BJ, Pitts JN, Chemistry of the Upper and Lower Atmosphere Theory, Experiments, and Applications, Academic Press, San Diego, CA,2000.

[6] Seinfeld JH, Pandis SN, Atmospheric Chemistry and Physics from Air Pollution to Climate Change,John Wiley and Sons, New York,NY,1998.

[7] Online Link: Medozons http//:www.medozons.com.

[8] Online Link : www. armorzone.com

[9] Thonomsub B, Anupunpisit V, Chanphetch S, Watchrachaipong T, Poonkhum R, Srisukonth C. effects of ozone treatment on cell growth and ultrastructural changes in bacteria,J Gen Appl Microbiol,48,2002,193-9.

[10] Tsengc,J environment health- Inactivation of surface viruses by gaseous ozone Lic, jun,70(10),2008,56-62 
[11] Seaverson K, Tschetter D, Kaur T, patient guide to oxygen/ozone therapy. Health centered cosmetic dentistry.

[12] Teresa B, Wolanska e, Cieszkobuk M, Orlowski M, Chalas R. Practical use of ozone in dentistry. Annales universitatis Marie Curie Sklodowska Lubin-Polonia, Vol LXIII, N 1,2004, 28 SECTION D.

[13] Seidler V, Linetskiy I, Hubalkova H, Stankova H., Smucler R., Mazanek J, Ozone and its usage in general medicine and dentistry.

[14] Lynch E, Leczeine prochnicy wylorzystaniem systemi healozon, 134,2004,3.

[15] Abu nabaa L, Management of primary occlusal pit and fissure caries using ozone, Belfast, UK, Queen's university,2003.

[16] Huth KC, Paschos E, Brand K, Hickel R, Effect of ozone on non cavitated fissure carious lesion in permanent molars a controlled prospective clinical study, Am J Dent 2005;223-28.

[17] Dahnhardt JE, Jaeggi T, Lussi A, Treating open carious lesion in anxious children with ozone, a prospective controlled clinical study, Am J Dent,19,2006,267-70.

[18] Zaura E, Buijs MJ, Ten Cate JM, Effects of ozone and sodium hypochlorite on caries-like lesion in dentin. Caries Res,41,2007,48492.

[19] Thomson VP, Karim JM, Non surgical treatment of incipient and hidden caries, Den clin North Am,49,2005,905-921.

[20] Homles J, Clinical reversal of root caries using ozone, double-blind, randamised controlled 18-month trial, Gerodontology ,20,2003,106-114.

[21] Azarpazhooh A, Limeback H, Lawrence H, Fillery Ed, Evaluating the effect of an ozone delivary system on the reversal of dentin hypersensitivity a randomised, double blinded clinical trial, J Endod ,35,2009,1-9.

[22] Cappuyns I, Gugerli P, Mombelli A, Viruses in periodontal disease A review, Oral Dis, 11,2005,219-29.

[23] Jarvensivu A, Hietanen J, Rautemaa R, Sorsa T, Ricardson M, Candida yeasts in chronic periodontitis tissues and subgingiival microflora biofilms in vivo ,Oral Dis, 10,2004,106-12.

[24] Bernstein D, Schiff G, Echler G, Purice A, Feller m, Briner W, In vitro virucidal effectiveness of a $0.12 \%$ chlorhexidine gluconate mouth rinse, J dent Res,69, 190,74-6.

[25] MarshPD, Sugar Flouride, pH and microbiota homeostasis in dental plaque, Proc Finn Dent Soc ,87,1991,515-25.

[26] Wilson M, Gibson M, Strahan D , Harvey W, A preliminary evalution of the use of redox agent in the treatment of chronic periodontitis, Res, 27,1992,522-7

[27] Marsh PD,Microbial ecology of dental plaque and its significance in health and diseases, Adv Dent Res ,8,1994,263-71.

[28] Mettraux GR, Gusberti FA, Graf H.Oxygen tension (pO2) in untreated human periodontal pockets, J clin Periodontontal,55,1984,516-21.

[29] Huth K. C, Jacob F.M. Effect of ozone on oral cells compared with established anti microbial,European journal of oral sciences, $114,2006,435-440$.

[30] Ebensberger U,Pohl Y, Fillipi A, PCNA expression of cementoblasts and fibroblast on the root surface after extra oral rinsing for decontamination,Dental traumatology,18,2002,262.

[31] Nagayoshi m, Fukuizumi T, Kitamura C, Yano J, Terashita M, Nishihara T, Efficacy of ozone and permeability of oral microorganisms, Oral microbiology and immunology,19,2004,240.

[32] Ramzy MI,Gomaa HE, Mostafa MI, Zaki BM, Management of aggressive periodontitis using ozonized water. Egypt. Med ,J.N.R C ,6(1),2005,229-45.

[33] Kshitisjh D, Laxman VK, The use of ozonated water and $0.2 \%$ CHX in treatment of periodontitis patients, A clinical and microbiological study. Indian J Dent Res 2010;341-8.

[34] Dodwad V, Gupta S, Kumar K, Sethi M, Massamatti S. Changing paradigm in pocket therapy-ozone versus conventional irrigation, Int $\mathrm{j}$ public health dent,2,2011,7-12.

[35] Fillipi A. The influence of ozonised water on the epithelial wound healing process in the oral cavity, Clinic of oral surgery, University of Basel, Switzerland.

[36] Karapetian Ve,Neugebauer J, Clausnitzer CE, Zoller JE, Comparison of different Periimplantitis Treatment methods.

[37] Priyamak AA.Ozone: The revolution in Dentistry, Copenhagen Quintessence publishing ,2004,55-64.

[38] Hems RS, Gulabivala K, Ng YL, Reddy D, Spratt DA, An in vitro evaluation of the ability of ozone to kill a strain of Enterococcus faecalis, Int Endod J,38,2005,22-9.

[39] Nogales CG, Ferrari PH, Kantarovich EO, Legw-Marques J, Ozone therapy in medicine and dentistry. J contemp Dent Pract,9,2008,1-9.

[40] Matsumura K, Hyon SH, Nakajima N, Iwata H, Watazu A, Tsutsumi S, Surface modification of polyethylene-co-vinyl alcohol hydroxyapatite immobilisation and control of periodontal cells differentiation, Biomaterials, 25,2006,4817-4824.

[41] Powers KA, Szaszi k,Khadharoo RG, Tawadros PS, Marshall JC, Kapus A, Rotstein OD, Oxidative stress generated by hemorrhagic shock recruits toll-like receptor 4 to the plasma membrane in macrophages. J Exp Med,203(8),2006,1951-1961.

[42] Kafoury RM, Pryor WA, Squadrito GL, Salgo MG, Zou X, Friedman M,Induction of inflammatory mediators in human airway epithelial cells by lipid ozonation products, Am J Respair Crit Care Med,160(6),1999,1934-1942.

[43] Uhlson C, Harrison K, Allen CB, Ahmed S, White CW, Murphy RC, Oxidised phospholipids derived from ozone treated lung surfactant extract reduce macrophage and epithelial cell viability, Chem Res Toxicol,15(7),2002,896-906.

[44] Bergamaschi E,De Palma G, Mozzoni P, Vanni S, Vettori MV, broeckaert F, Bernard A, Mutti A. polymorphism of quinonemetabolising enzymes and suspectability to ozone induced acute effects, Am J Respir Crit Care med,163(6),2001,1426-1431.

[45] Chen C, Arjomandi m, Tager IB, Holland N, Balmes JR, Effects of antioxidant enzyme polymorphisms on ozone-induced lung function changes, Eur Respir J,30(4),2007,677-683.

[46] Alexeeff SE, Litonjua AA, Wright RO, Baccarelli A, Suh H, Sparrow D, Vaokonas PS, Schwartz J, Ozone exposure, anti-oxidant genes and lung function in an elderly cohort, VA normative aging study,Occup Environ Med ,65(11)2008,73 -742. 